\title{
Building Tolerance Attitudes Of PPKN Students Through Multicultural Education Courses
}

\author{
Jagad Aditya Dewantara ${ }^{1)}$, T Heru Nurgiansah ${ }^{2)}$ \\ Civic Education Study Program of the Faculty of Teacher Training and Education of Universitas \\ Tanjungpura Pontianak, Indonesia ${ }^{1)}$ \\ Civic Education Study Program of the Faculty of Teacher Training and Education of Universitas PGRI \\ Yogyakarta. PGRI I Sonosewu street No.117, Yogyakarta, Indonesia ${ }^{2)}$ \\ jagad02@ fkip.untan.ac.id ${ }^{1)}$, nurgiansah@upy.ac.id ${ }^{2)}$
}

\begin{abstract}
Lately ethnocentric attitudes or understand the area in the college environment are increasing. Discrimination against Sara is still occurring. If this is continued, it will further create division between the nation's children. This research aims to build tolerance among students to create unity and unity through the provision of Multicultural Education courses. This research uses qualitative methods with technical data collection through observation, interviews, documentation, and literacy studies. The results of this study show that multicultural education courses have managed to form a tolerance attitude among students of Pancasila Education and Citizenship of PGRI University Yogyakarta. Student tolerance is reflected in the implementation of lectures in the classroom, during the work of both individuals and groups, and during the implementation of the Final Semester Exam.
\end{abstract}

Keywords: Tolerance; Student; Multicultural Education

\begin{abstract}
Abstrak. Akhir-akhir ini sikap etnosentris atau faham kedaerahan di lingkungan perguruan tinggi semakin meningkat. Diskriminasi atas sara masih terjadi. Jika hal ini terus menerus dibiarkan akan semakin menimbulkan perpecahan antar anak bangsa. Penelitian ini bertujuan untuk membangun sikap toleransi dikalangan mahasiswa agar terciptanya persatuan dan kesatuan melalui pemberian mata kuliah Pendidikan Multikultural. Penelitian ini menggunakan metode kualitatif dengan tekniik pengumpulan data melalui observasi, wawancara, dokumentasi, dan studi literasi. Hasil penelitian ini menunjukan bahwa mata kuliah Pendidikan Multikultural telah berhasil membentuk sikap toleransi dikalangan mahasiswa Pendidikan Pancasila dan Kewarganegaraan Universitas PGRI Yogyakarta. Sikap toleransi mahasiswa tercermin saat pelaksanaan perkuliahan di kelas, saat pengerjaan tugas baik individu maupun kelompok, dan pada saat pelaksanaan Ujian Akhir Semester.
\end{abstract}

Kata Kunci: Toleransi; Mahasiswa; Pendidikan Multikultural 


\section{INTRODUCTION}

The Unitary State of the Republic of Indonesia is the largest country in the Southeast Asia region. Geographically, the territory of Indonesia is squeezed by two continents and two oceans, namely the Asian Continent and the Australian Continent, as well as the Indian Ocean and the Pacific Ocean. Indonesia is also the largest archipelago in the world because it has more than 17,000 islands stretching from the western tip of Sumatra to the eastern tip of the mainland of Papua. With its vast territory, Indonesia is rich in natural resources and a variety of ethnicities, languages and cultures. This diversity is united in the framework of Bhineka Tunggal Ika which means pluralist but still one unity. Philosophically, multicultural means the diversity that forms acculturation in society. On the one hand, this diversity is very beneficial and makes Indonesia's name fragrant in international circles. But on the other hand, this actually creates a complex problem. Indonesia is a pluralistic country that has diversity of ethnicities, religions, races, customs and cultures. The plurality of the Indonesian nation makes it prone to conflict, both horizontal and vertical conflicts, and prone to fighting over interests between groups that can threaten the integrity, sovereignty and peace in the life of society, nation and state (Arisona, 2019).

To avoid this problem, we need a method and solution so that the value of unity is maintained and guaranteed. One of these solutions is to provide understanding to the community about the importance of unity and unity in diversity, namely through Multicultural Education. Multicultural education is a movement in terms of renewal and a process to create an equal educational environment for all students without discriminating against their background, social status, and economic level (Cahyono \& Iswati, 2017).

It has been previously mentioned that the face of multiculturalism in Indonesia to date has been likened to a fire in the husks, which one day could arise due to the heating up of political, religious, social and cultural temperatures, which have allowed the conflict to re-emerge. This means that this kind of polemic keeps repeating itself without end (Sangadji, 2016). A country with diverse community conditions will be very vulnerable to a conflict (Sriwahyuningsih \& Doni, 2018).

Multicultural education should include things such as applying tolerance, developing themes about ethnocultural and religious differences, explaining the dangers of discrimination, ways of peaceful conflict resolution without violence and bloodshed, realizing human rights, the importance of attitudes. democracy and plurality, universal humanity, law enforcement that provides a sense of justice for all warring parties, and other relevant subjects (Supriatin \& Nasution, 2017). 
Multicultural ideology needs to be instilled from an early age in our children so that the national character of our future generations will be stronger (Awaru, 2017). The multiculturalism that was formed in Indonesia was the result of the diverse and extensive socio-cultural and geographical conditions. Lately, there has been less obedience in carrying out religious orders, there is no longer a sense of caring for and helping each other so that the mentality of the younger generation is increasingly damaged (Herawan \& Sudarsana, 2017). By instilling a multicultural ideology, there is no need to worry about friction between layers of society. This is also done so that students do not fall into negative things (Nurgiansah \& Sukmawati, 2020).

The incident of Papuan student riots in Surabaya and Malang in April 2019 is concrete evidence that if the diversity of the Indonesian nation is not managed properly, discrimination against Sara cannot be avoided. This incident has succeeded in making us open our eyes and ears that even among academics there can be conflicts just because of differences in ethnicity. And it turns out that conflicts like this do not only occur in society but are starting to shift among students. In this case, the tertiary institution must be sensitive in assessing all the problems on how to prevent similar incidents from occurring on other campuses. Not only that, there are various problems caused by the multicultural
Indonesian society, including the widening socio-political gap, legal injustice, and promiscuity that violates the boundaries of norms that apply in society (Setiawan, 2014).

One of these solutions was outlined in Sriwahyuningsih's 2018 research on the implementation of multicultural education values at the Muhammadiyah University of Gorontalo, he said that it is necessary to instil multicultural education values which will have a positive impact on the tolerance attitudes of students at the Muhammadiyah University of Gorontalo. This positive attitude is in the form of students' attitude to interact and cooperate with anyone with a sense of security and comfort without any mutual suspicion. This attitude of tolerance is also part of multicultural action, where living together in a harmonious atmosphere can only be achieved if every student has an attitude of tolerance. This attitude of tolerance can only grow if students understand the essence of multicultural education.

Multicultural education is a process of understanding teaching material in society so that they can respect others, respect differences, and equalize the position of various ethnic groups, cultures and religions without discrimination. Thus, the community will be able to live side by side in diversity and the condition of the nation's character which is increasingly apprehensive (Setiawan, 2014).

The purpose of cultural education itself can be divided into two domains, namely 
aspects of attitude and aspects of knowledge. The purpose of multicultural education related to attitudinal aspects is to develop awareness and cultural sensitivity, different cultural tolerances, respect for the cultural identity inherent in each individual or group, responsive attitudes to the culture that develops in the surrounding community, skills to avoid and resolve or resolve conflicts as a whole by peaceful means, without violence, without bloodshed, and without the use of weapons. Meanwhile, the goals of multicultural education related to the cognitive goals are to obtain all information and knowledge about the language and culture of others and can analyze and translate cultural behaviour and knowledge (Zuriah, 2011). The knowledge aspect emphasizes students' understanding of the developing theory of multicultural education, while the attitude aspect emphasizes the behaviour, actions, or actions of students towards previously acquired knowledge.

The formation of a tolerant national character needs serious attention from various parties, from the government to universities, so that every member of society is capable and able to accept differences which should be one of the characteristics of the Indonesian nation. The formation of a tolerant national character will also be able to prevent people from conflict-laden with interests (Kelly, 2018).

The conflicts that occurred in Indonesia encouraged the importance of educational transformation that prioritizes the formation of national character (Agustian et al., 2018). One of the character values that can foster an attitude of tolerance is religious character. Religious character means being a devout person in worshipping God, having an attitude of tolerance towards different beliefs, and striving to live in harmony with people of different religions (Nurgiansah et al., 2020). Religious character means being a person who is devout in worshipping God, has an attitude of tolerance towards different beliefs, and strives to live in harmony with people of various religions.

\section{RESEARCH METHODS}

This research used a case study with a qualitative approach. The case study was chosen because there was a unique phenomenon that was different because the application of the Multicultural Education course at the PGRI Yogyakarta University was not only a theory but was practised in the Diversity Parade which was routinely held every year. By using a qualitative approach, researchers focused on attention and also natural events (Nurgiansah \& Widyastuti, 2020). This research was conducted at PGRI Yogyakarta University in the Pancasila and Citizenship Education Study Program with the target of 20 third semester students. Data collection techniques using observation, interviews, documentation, and literacy. Observations were made by researchers by 
taking regular lectures for 15 meetings so that they could get accurate data about Multicultural Education courses. Interviews were conducted with lecturers who teach Multicultural Education Courses and some students. The interview was a data collection with a path of question and answer that was conducted systematically and based on the purpose of an investigation, to obtain the complete data, clear and precise the author held the question and answer to the official or the competent (Nurgiansah, 2020). Interviews were needed to obtain accurate and important information to support research on competent and relevant informants in the problem being studied. Documentation was carried out as an archiving effort so that the data that had been obtained did not just disappear or change its meaning. Then the last one was literacy, this was done by collecting and reading journal articles on tolerance and multicultural education.

\section{DISCUSSION}

Multicultural Education courses are special courses taught in the Pancasila and Citizenship Education Program at PGRI Yogyakarta University with a weight of 5 credits and are given to 3rd-semester students. The lecturer in charge of this course is Dra. Rosalia Indriyati Saptatiningsih, M.Si. and Dr Septian Aji Permana, M.Pd.

The lecture is held in 15 meetings. At the beginning of the meeting, PPKn students at
PGRI Yogyakarta University seemed not to mingle with each other even though this was already in their third semester. Students are still seen in groups based on similarities in their origin. Students still have an awkward impression of communicating with their friends who come from different provinces. To get around this, students were divided into 5 groups with each group of 4 students. The names of the groups were given with the names of the ethnic groups and the names of the group members were randomized so that the students would mingle with one another. The following is the group distribution table:

Table 1.Group Division

\begin{tabular}{|c|c|}
\hline Name of Group & Name of student \\
\hline \multirow{3}{*}{ Batak } & IEQ \\
& FRM \\
& DU \\
& APA \\
\hline \multirow{3}{*}{ Betawi } & NH \\
& IINH \\
& IMDA \\
MRC \\
\hline \multirow{3}{*}{ Sunda } & FNS \\
& MJ \\
& ADP \\
& AS \\
\hline \multirow{3}{*}{ Jawa } & RDP \\
& M \\
& W \\
Dayak & TH \\
& RM \\
& NFR \\
& RRR \\
\hline
\end{tabular}

Even though there are only 5 groups or

5 ethnic groups, in carrying out their duties each group member discusses 1 ethnic group so that in 1 group discuss 4 ethnic groups in Indonesia, including the name of the tribe, the 
area of distribution, language, traditional clothes, regional songs, traditional houses, the majority of their livelihoods, and their distinctive weapons. After all, groups were ready with the data, then a weekly group presentation was held in turn. With learning activities like this, students' knowledge of Indonesia's diversity will increase and can foster an attitude of tolerance among their peers.

The following is the material presented by each group:

Table 2.Batak Group

\begin{tabular}{|l|l|}
\hline \multicolumn{1}{|c|}{$\begin{array}{c}\text { Name of } \\
\text { Tribe }\end{array}$} & \multicolumn{1}{|c|}{ Batak } \\
\hline $\begin{array}{l}\text { Area of } \\
\text { Distribution }\end{array}$ & $\begin{array}{l}\text { Most of the province of } \\
\text { Sumatra Utara }\end{array}$ \\
\hline Language & $\begin{array}{l}\text { Batak language, for example, } \\
\text { "Horas" }\end{array}$ \\
\hline $\begin{array}{l}\text { Traditional } \\
\text { Custom }\end{array}$ & $\begin{array}{l}\text { Ulos cloth, Toba Batak } \\
\text { traditional clothing, etc. }\end{array}$ \\
\hline Folk Song & $\begin{array}{l}\text { "Siksiksibatumanikam", } \\
\text { "Mariam Tomong", }\end{array}$ \\
\hline $\begin{array}{l}\text { Custom } \\
\text { Home }\end{array}$ & $\begin{array}{l}\text { "Gorga Traditional House } \\
\text { ", Bolon Traditional House }\end{array}$ \\
\hline livelihood & $\begin{array}{l}\text { Most of the Batak people } \\
\text { cultivate crops in irrigation } \\
\text { and fields }\end{array}$ \\
\hline $\begin{array}{l}\text { Traditional } \\
\text { Weapon }\end{array}$ & "Piso Gaja Dompak" \\
\hline
\end{tabular}

Table 3.Betawi Group

\begin{tabular}{|l|l|}
\hline \multicolumn{1}{|c|}{$\begin{array}{c}\text { Name of } \\
\text { Tribe }\end{array}$} & \multicolumn{1}{|c|}{ Betawi } \\
\hline $\begin{array}{l}\text { Area of } \\
\text { Distribution }\end{array}$ & Province of DKI Jakarta \\
\hline Language & $\begin{array}{l}\text { Indonesian with a typical } \\
\text { Betawi dialect }\end{array}$ \\
\hline $\begin{array}{l}\text { Traditional } \\
\text { Custom }\end{array}$ & $\begin{array}{l}\text { Demang Clothes,Ujung } \\
\text { serong Clothe }\end{array}$ \\
\hline Folk Song & $\begin{array}{l}\text { "Ondel-ondel", "Jali-jali", } \\
\text { "Keroncong Kemayoran" }\end{array}$ \\
\hline
\end{tabular}

\begin{tabular}{|l|l|}
\hline $\begin{array}{l}\text { Custom } \\
\text { Home }\end{array}$ & $\begin{array}{l}\text { "Kebaya House”, "Joglo } \\
\text { House” }\end{array}$ \\
\hline livelihood & Farmers, Laborers. \\
\hline $\begin{array}{l}\text { Traditional } \\
\text { Weapon }\end{array}$ & "Bendo", "Golok" \\
\hline
\end{tabular}

Table 4.Sunda Group

\begin{tabular}{|c|c|}
\hline $\begin{array}{c}\text { Name of } \\
\text { Tribe }\end{array}$ & Sunda \\
\hline $\begin{array}{l}\text { Area of } \\
\text { Distribution }\end{array}$ & $\begin{array}{l}\text { Most of the provinces of } \\
\text { West Java and Banten. } \\
\text { However, the majority of } \\
\text { Cirebon and Indramayu } \\
\text { districts are Javanese. }\end{array}$ \\
\hline Language & $\begin{array}{l}\text { Sundanese, examples of } \\
\text { commonly used vocabulary: } \\
\text { "Wilujeung } \quad \text { Sumping" } \\
\text { (Welcome), } \\
\text { Kabarna?" (How are you?a) }\end{array}$ \\
\hline $\begin{array}{l}\text { Traditional } \\
\text { Custom }\end{array}$ & $\begin{array}{l}\text { Kebaya Sunda, Pangsi, } \\
\text { Bedahan, Menak. }\end{array}$ \\
\hline Folk Song & $\begin{array}{l}\text { "Manuk Dadali", } \\
\text { "Borondong Garing", } \\
\text { "Mojang Priangan", "Es } \\
\text { Lilin", etc }\end{array}$ \\
\hline $\begin{array}{l}\text { Custom } \\
\text { Home }\end{array}$ & $\begin{array}{l}\text { "Imah Saung Ranggon", } \\
\text { "Imah Badak Heuay" }\end{array}$ \\
\hline livelihood & $\begin{array}{l}\text { Most of the Sudanese people } \\
\text { who live in mountainous } \\
\text { areas are mostly farming and } \\
\text { gardening which includes } \\
\text { Sumedang Regency, } \\
\text { Majalengka Regency, while } \\
\text { people in coastal areas make } \\
\text { their livelihoods as fishermen } \\
\text { which includes Pangandaran } \\
\text { Regency, Tasikmalaya } \\
\text { Regency, Sukabumi regency, } \\
\text { etc }\end{array}$ \\
\hline $\begin{array}{l}\text { Traditional } \\
\text { Weapon }\end{array}$ & $\begin{array}{l}\text { "Kujang", "Bedog", } \\
\text { "Baliung". ect }\end{array}$ \\
\hline
\end{tabular}

Table 5.Jawa Group

\begin{tabular}{|c|c|}
\hline $\begin{array}{l}\text { Name of } \\
\text { Tribe }\end{array}$ & Jawa \\
\hline $\begin{array}{l}\text { Area of } \\
\text { Distribution }\end{array}$ & $\begin{array}{l}\text { Most of them are in the } \\
\text { provinces of Central Java, } \\
\text { East Java and the Special } \\
\text { Region of Yogyakarta }\end{array}$ \\
\hline
\end{tabular}




\begin{tabular}{|l|l|}
\hline Language & Java \\
\hline $\begin{array}{l}\text { Traditional } \\
\text { Custom }\end{array}$ & "Jawi Jangkep", "Batik" \\
\hline Folk Song & $\begin{array}{l}\text { "Suwe Ora Jamu”, } \\
\text { "Tokecang." }\end{array}$ \\
\hline $\begin{array}{l}\text { Custom } \\
\text { Home }\end{array}$ & "Rumah Joglo" \\
\hline livelihood & Farmers, Fishermen, etc. \\
\hline $\begin{array}{l}\text { Traditional } \\
\text { Weapon }\end{array}$ & ceremonial knife \\
\hline
\end{tabular}

Table 6.Dayak Group

\begin{tabular}{|l|l|}
\hline \multicolumn{1}{|c|}{$\begin{array}{c}\text { Name of } \\
\text { Tribe }\end{array}$} & \multicolumn{1}{c|}{ Dayak } \\
\hline $\begin{array}{l}\text { Area of } \\
\text { Distribution }\end{array}$ & $\begin{array}{l}\text { The majority inhabit the } \\
\text { island of Kalimantan }\end{array}$ \\
\hline Language & Malay \\
\hline $\begin{array}{l}\text { Traditional } \\
\text { Custom }\end{array}$ & "Sapei Sapaq" \\
\hline Folk Song & "Taringat Ka' Kao" \\
\hline $\begin{array}{l}\text { Custom } \\
\text { Home }\end{array}$ & "Betang House" \\
\hline livelihood & $\begin{array}{l}\text { Farming, } \\
\text { Gardening }\end{array}$ \\
\hline $\begin{array}{l}\text { Traditional } \\
\text { Weapon }\end{array}$ & "Mandau" \\
\hline
\end{tabular}

Tolerance itself has several principles, namely mutual respect, mutual acceptance, and mutual respect for cultural diversity, customs, languages, and religions/beliefs inhumane ways by the second principle of Pancasila, namely fair and civilized humanity. Tolerance means being harmonious in interpreting the differences. Besides, tolerance is also synonymous with behaviour that does not deviate from the applicable rules and respects each other's actions.

The tolerance attitude of PPKn students at PGRI Yogyakarta University is influenced by two factors, namely internal factors and external factors. Internal factors consist of personality, self-control, and ethnocentrism. External factors consist of the educational environment, social identity, and religious fundamentalists.

Student personality factors are divided into two types, the personality type here is the extrovert type with open characteristics so that it is willing to accept differences, is relaxed about different situations, is active and tends to be optimistic in doing certain activities and the introvert type with closed characteristics, passive and tend to be pessimistic. Introvert types are more intolerant than extrovert types (Kelly, 2018).

The next internal factor is student selfcontrol as one of the personality traits that distinguish one student from another. High self-control will be able to change circumstances and become a tool to direct and regulate behaviour in a better direction. The last internal factor is ethnocentrism, which is the attitude of students who tend to see the values and norms of their cultural group as the best and are used as a standard to judge and act on other cultures or feel that their own culture is better than other cultures. The higher the ethnocentric attitude, the more intolerant the attitude, as well as the lower the ethnocentric attitude, the more tolerant the student has.

In addition to the internal factors above, the tolerance attitude of students is also influenced by external factors, including the educational environment; tolerance is passed from previous generations to the next through 
the process of socialization, assimilation, and the transformation of knowledge about the culture. The educational environment used in the process of socialization, assimilation and information is the family environment, school environment and community environment which will shape the mental personality of each individual.

The second external factor is social identity, which is a condition in which each individual applies cognitive and motivational processes in placing himself in a group as part of his cultural existence efforts. And the last one is religious fundamentalism, religion is a paradoxical thing because religion can lead to tolerance among religious communities, and it can also cause intolerance.

Apart from dividing groups and presenting cultural diversity in Indonesia, lecture activities were also filled with the task of studying journals on multicultural education. Because according to Dr. Septian Aji Permana, M.Pd, as a lecturer in multicultural education I, in general, lectures at PPKn PGRI Yogyakarta University use the journal review method with the hope that student knowledge will increase. And at the end of the meeting, students were given the task of wearing uniforms or traditional clothing from their respective regions, which were then given the name of the activity "Parade of Diversity". Meanwhile, according to Dra. Rosalia Indriyati Saptatiningsih, M.Si, as a lecturer of multicultural education II, this course is not only about theory, but must be put into practice.

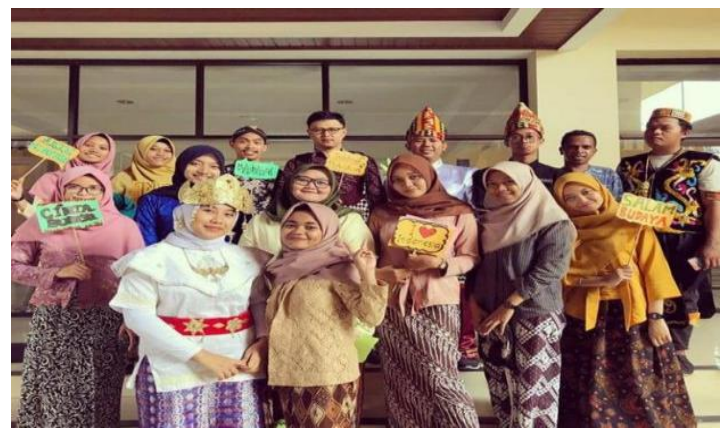

Figure 1. Implementation of Multicultural Education

The picture above is the final project of the Multicultural Education course for PPKn students at PGRI Yogyakarta University. The final project is to instruct students to be able to implement the diversity of Indonesian culture by wearing their respective regional traditional clothes. It is intended that PPKn students of PGRI Yogyakarta University understand and realize that Indonesian culture is very diverse so that with this awareness it will foster a love for their own culture and increase tolerance among fellow students without differentiating their origin, language, and culture.

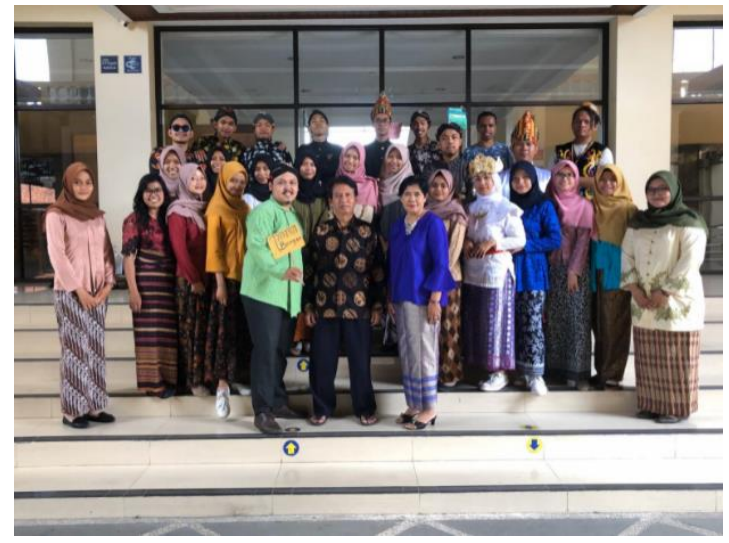

Figure 2. "Parade of Diversity" with Head of Study Program and Lecturers 
The characteristics or principles of multicultural education courses consist of: first, the principles of democracy, equality, and justice. Second, oriented towards humanity, togetherness and peace. And third, develop an attitude of acknowledging, accepting, and respecting diversity.

In the first principle, the principle of democracy means freedom in terms of expressing cultural existence without any pressure. In classroom learning, students are given the freedom to improvise their way of learning, free to express opinions, free to ask questions, and free to refute their friends' arguments. In terms of equality, students are placed on an equal footing and guarantee their rights to receive teaching exclusively. And in the principle of justice, students are not treated differently.

In the second principle, the principle of humanity means treating students according to their dignity as human beings and not being treated arbitrarily. The principle of togetherness includes the unity of understanding, feelings, knowledge, and attitudes in the relationship between one student and another, even though they have differences in ethnicity, culture, language, religion, race, ethnicity and social and economic strata. Then the principle of peace, students try not to do attitudes and behaviours that can hurt the feelings of other students either with words or deeds and avoid things that are detrimental to other students.
In the third principle, the attitude of accepting, recognizing and appreciating diversity is very important in everyday lectures among diverse students. In social life, there are dominant and minority sections of society. With an attitude of accepting, acknowledging and respecting diversity, it creates a harmonious relationship and there is no arbitrary attitude from the dominant party to the minority party.

Multicultural education can be implemented in a curriculum unit. The implementation of multicultural education into the curriculum is mandatory for implementation. A curriculum that is based on multiculturalism, which is a curriculum that contains the values of pluralism and tolerance for diversity.

Multicultural education has four concepts. The first is multicultural education is teaching about the cultural diversity of the archipelago as an approach to cultural assimilation. As we all know that the Indonesian State is very pluralist, this has an impact on students who are spread across universities who do not come from the same area but come from all corners of the country so that it will result in assimilation or cultural fusion.

The second concept, multicultural education is the teaching of various approaches in terms of social relations in society (Dewantara et al., 2020). This subject emphasizes how social relations among the 
community can be established in the frame of peace. If this happens, the value of Indonesia's unity and integrity will not be scattered. This concept also teaches the relationship between fellow humans so that there is a strong inner and outer bond so that it is not easily provoked and causes noise to endless conflicts.

The third concept, multicultural education is teaching to promote pluralism or diversity without distinguishing the existing social strata in society. Today, the caste system is no longer a frightening specter. The origins of all groups and strata of society are no longer differentiated.

The fourth concept, multicultural education is teaching about a reflection of diversity to increase pluralism and equality that is framed by Bhineka Tunggal Ika.

Apart from the concept of multicultural education, several components can be used as basic competencies for multicultural education courses. Among them: first, by studying multicultural education, PPKn students of PGRI Yogyakarta University are expected to be good citizens, who can accept and appreciate every difference, be it ethnic differences, religious differences. differences in language, as well as cultural differences in the hierarchical structure of society.

The second basic competency, by studying multicultural education, PPKn students of PGRI Yogyakarta University are expected to become state warriors who can carry out mutually beneficial cooperation regardless of differences in cultural backgrounds, languages, religions and customs, so that this collaboration is multiethnic, multicultural, and multi-religious which will develop and be useful in the context of sustainable economic development and national strength.

The third basic competency, after being equipped with multicultural education courses, PPKn students of PGRI Yogyakarta University are expected to become citizens who are able to respect each of the individual rights of other citizens regardless of ethnic background, religion, language, customs, culture, strata. social and economic strata in all sectors or spheres of life, covering the social, political, legal, educational, economic and cultural fields in the framework of maintaining national unity and integrity and as an effort to promote and develop the surrounding culture.

Furthermore, the fourth basic competency, after studying multicultural education, PPKn students of PGRI Yogyakarta University are required to become citizens who provide equal opportunities to all citizens to be represented in governmental institutions, both legislative and executive, at both levels. central and regional levels so that rights in politics can be properly channeled.

And the fifth basic competence, equipped with multicultural education courses, PPKn students of PGRI Yogyakarta University are trained to become citizens who 
are able to develop a fair attitude towards others and develop a sense of justice for all parties without discrimination or differences in treatment on the basis of differences in ethnic backgrounds, their religious backgrounds, differences in language and culture.

Then the sixth basic competence, through multicultural education, PPKn students of PGRI Yogyakarta University are expected to become citizens who have multicultural attitudes and habits based on tolerant attitudes and behaviors among all the nation's children, solidarity, feel the suffering of others, and can work together For the benefit of society, nation and state, be egalitarian, have empathy among fellow citizens, and act fairly without differentiating between religious background, race, language and skin color.

With these six basic competencies, the tolerance attitude of PPKn students at PGRI Yogyakarta University is increasing. And after one semester, PPKn students of PGRI Yogyakarta University attended lectures on multicultural education courses, the attitude of students was increasingly tolerant, this was evident from the behaviour of students who increasingly mingled without feeling any more awkwardness. They know each other and are increasingly open to understanding differences, both in terms of culture and in terms of beliefs. Thus, this course has succeeded in building student tolerance. The educational process can ultimately increase student tolerance, either through habituation or through compliance with regulations (Novitasari et al., 2019).

Research on tolerance and multiculturalism has been done a lot, for example, research from Estalita in 2018 regarding the formation of tolerant attitudes of students at Yudharta Pasuruan University through the Multicultural Education course, the results of his research state that student tolerance can be formed through these courses. It's just that the weakness of this research is the method used using quantitative studies so that the data obtained is less than optimal. As for this research, the data obtained is more systematic and coherent because it uses qualitative studies so that it raises the novelty that this course does not only contain theories in lectures, but there is a direct practice through diversity parades as the final project of its students.

Another novelty is that the learning outcomes of Multicultural Education courses have been adjusted to the paradigms that occur in the field so that the material content can be understood by students easily. And finally, lecturers play an active role in forming student tolerance because the learning activities in them and the way of delivering the material use learning innovations that are fun, to the point, and become aspirational figures for students. 


\section{CONCLUSION}

Multicultural Education Course is one of the courses that aim to make PPKn students of PGRI Yogyakarta University the importance of implementing an attitude of tolerance among others. Students' tolerance attitude is reflected in daily behaviour in the college environment such as greeting each other, helping each other with assignments, not discriminating in interactions, not making fun of each other, and understanding language and cultural differences.

The content of the material in the Multicultural Education course is also very innovative. Not only in the form of theories but implemented in lecture assignments such as wearing the traditional clothing of their respective regions, giving rise to love for cultural diversity in Indonesia

\section{REFERENCES}

[1] Agustian, M., Anindyta, P., \& Grace, M. (2018). Mengembangkan Karakter Menghargai Perbedaan Melalui Pendidikan Multikultural. Jurnal Bakti Masyarakat Indonesia, 1(2), 191-199.

[2] Arisona, R. D. (2019). Pendidikan Multikultural pada Mata Kuliah Konsep Dasar Ips Sebagai Upaya Pencegahan Sikap Radikalisme Mahasiswa Tadris Ips Iain Ponorogo. Proceedings of Annual Conference for ..., 17(1), 73-80.

[3] Awaru, A. O. T. (2017). Membangun Karakter Bangsa Melalui Pendidikan Berbasis Multikultural Di Sekolah. Prosiding Seminar Nasional Himpunan Sarjana Ilmu-Ilmu Sosial, 2, 221-230.

[4] Cahyono, H., \& Iswati, I. (2017). Urgensi
Pendidikan Multikultural Sebagai Upaya Meningkatkan Apresiasi Siswa Terhadap Kearifan Budaya Lokal. Elementary: Jurnal Ilmiah Pendidikan Dasar, 3(1), $15-28$.

https://doi.org/10.32332/elementary.v3i1 .771

[5] Dewantara, J. A., Efriani, Sulistyarini, \& Prasetiyo, W. H. (2020). Optimization of Character Education Through Community Participation Around The School Environment ( Case Study in Lab School Junior High School Bandung ). Jurnal Etika Demokrasi, 5(1), 53-66.

[6] Herawan, K. D., \& Sudarsana, I. K. (2017). Relevansi Nilai Pendidikan Karakter Dalam Geguritan Suddhamala Untuk Meningkatkan Mutu Pendidikan di Indonesia. Jurnal Penjaminan Mutu, 3(2), 223-236.

[7] Kelly, E. (2018). Pembentukan Sikap Toleransi Melalui Pendidikan Multikultural Di Universitas Yudharta Pasuruan. Jurnal Psikologi, 5(1), 21-28.

[8] Novitasari, D., Ladamay, I., \& Wadu, L. B. (2019). Upaya Pembentukan Karakter Religius Islam pada Siswa Melalui Keteladanan di Sekolah Menengah Kejuruan. Prosiding Seminar Nasional, 3, 174-181.

[9] Nurgiansah, T. H. (2020). Build An Attitude of Nationalism Students At SDN 7 KADIPATEN With The Method of Discusion In The Subject PPKn. Jurnal Serunai Pendidikan Pancasila Dan Kewarganegaraan STKIP Budi Daya Binjai, 9(1), 1-11.

[10] Nurgiansah, T. H., Dewantara, J. A., \& Rachman, F. (2020). The Implementation of Character Education in the Civics Education Syllabus at SMA Negeri 1 Sleman. Jurnal Etika Demokrasi Universitas Muhammadiyah Makasar, 5(2), 110-121. 
[11] Nurgiansah, T. H., \& Sukmawati. (2020). Tantangan Guru Pendidikan Kewarganegaraan Di Masa Adaptasi Kebiasaan Baru. Jurpis: Jurnal Pendidikan Ilmu Sosial, 17(2), 139-149.

[12] Nurgiansah, T. H., \& Widyastuti, T. M. (2020). Membangun Kesadaran Hukum Mahasiswa PPKn UPY Dalam Berlalu Lintas. Civic Edu: Jurnal Pendidikan Kewarganegaraan Universitas Pasundan, 2(2), 97-102. https://doi.org/10.1017/CBO9781107415 324.004

[13] Sangadji, K. (2016). Pendidikan Multikultural Dalam Pengembangan Kurikulum Perguruan Tinggi. Jurnal Biology Science \& Education, 5(1), 3845.

[14] Setiawan, D. (2014). Pendidikan Kewarganegaraan Berbasis Karakter melalui Penerapan Pendekatan Pembelajaran Aktif, Kreatif, Efektif dan Menyenangkan. Jurnal Pendidikan IlmuIlmu Sosial, 6(2), 61-72.

[15] Sriwahyuningsih, R. S., \& Doni, C. P. (2018). Penanaman Dan Implementasi Nilai Pendidikan Multikultural (Studi Kasus Di Universitas Muhammadiyah Gorontalo). Education Journal: Journal Educational Research and Development, 2(1), 41-58.

[16] Supriatin, A., \& Nasution, A. R. (2017). Implementasi Pendidikan Multikultural Dalam Praktik Pendidikan Di Indonesia. Elementary: Jurnal Ilmiah Pendidikan Dasar, 3(1), 1-13. https://doi.org/10.32332/elementary.v3i1 .785

[17] Zuriah, N. (2011). Model Pengembangan Pendidikan Kewarganegaraan Multikultural Berbasis Kearifan Lokal Dalam Fenomena Sosial Pasca Reformasi Di Perguruan Tinggi. Jurnal Penelitian Pendidikan, 2(2), 63-72. 